\title{
JOÃO PAULO DE ALMEIDA MAGALHÃES
}

Eu conheci poucos economistas tão empenhados em defender o interesse público quanto foi João Paulo de Almeida Magalhães, falecido no último 17 de setembro, aos 88 anos. Eu o conhecia há muitos anos. A primeira vez que o vi foi quando obteve o título de Livre Docente na Faculdade de Direito de São Paulo, da USP, creio que em 1954. Um pouco antes, havia completado seu doutoramento na Universidade de Paris, Sorbonne. E um pouco mais tarde, tornou-se professor titular de Economia das Faculdades de Direito da Universidade Federal do Rio de Janeiro. Em pouco tempo ele se tornou um dos economistas desenvolvimentistas mais respeitados no Brasil. Como bom desenvolvimentista, estava associado à indústria nacional, e foi durante algum tempo diretor do Departamento de Estudos Econômicos da Confederação Nacional da Indústria. Exerceu, depois, muitos cargos públicos, e foi presidente do CORECON do Rio de Janeiro por seis mandatos, tendo o último terminado em 2012.

No plano acadêmico, João Paulo de Almeida Magalhães tornou-se um dos economistas desenvolvimentistas mais respeitados do Brasil quando, em 1961, publicou o livro A Controvérsia Brasileira sobre o Desenvolvimento Econômico. Publicou depois muitos livros, o último dos quais foi Brasil Século XXI, uma Alternativa ao Neoliberalismo. Nesta revista, ele publicou vários artigos, o último previsto para publicação no n. 36 (1) de 2016 é "Crescimento clássico e crescimento retardatário: um novo enfoque para políticas de desenvolvimento”. Um de seus amigos mais diletos foi Hélio Jaguaribe - um fundador do desenvolvimentismo brasileiro - com quem partilhou uma visão do Brasil sempre voltada para o futuro.

Luiz Carlos Bresser-Pereira Editor 